\title{
LOG AND OTHER POEMS
}

\author{
Vyxz Vasquez \\ lhvasquez@up.edu.ph \\ University of the Philippines Diliman
}

\section{About the Author}

Vyxz Vasquez teaches creative writing and English at the University of the Philippines Diliman. 
1. Take this body, submerged. Take these hands floating above you. Take the soul and the rest should follow. Take my lobes, the milky white film around my eyes, take them home. There are windows and windows upon windows. There are shadows. Here is a box filled with sorrow. Here is a chart for your weakness. Though you are here, waiting to happen. Take this man and give him your part. Take the vital statistics. Twist the ties on this corset and draw some air. Maybe then there will be pain. Some drowning

2. There is no opposite. A pose of sound. Caramel whisked on a stainless bowl. Without air, no travel. Without a home, no maps

3. My waking is filled with desire. Little things done to get to that point, that tangent of space and time. Every waking is done to dream again. I look for the dead to reappear in this dream and no matter how forceful, there are no traces

4. I kiss your hands, your body, skin bursting with sound

5. Here is the ground. Here is my face on the ground. Water fast rising, soon to embrace us

6. I jump and plunge myself deep into the navel of the earth. Deep that the possibility of sound does not come. And there is no one there, nothing I can see

7. Take my hands, take my body and this water

8. One day we had little need for anything all we had was music all we had was body there was bleeding but no pain there was sorrow but random rays there were parts unreceived and unrehearsed there were no opposites nor no crevices there was only you and me in the dream

9. There where there is thoroughness and looseness. My skin and its folds, the body spreads like water, set loose upon the earth 
10. Your hands are on your stomach—-they'd rather that than the sides. My arms I fold to myself, and you pry them open

11. A boy with a kite running somewhere

12. We all long for the womb. This is why the world feels much too large, vacant

13. What if one day, we no longer recognize our bodies? Is this what makes us human? Our shapes?

14. For now, I am diving in wreckage. Signs of life everywhere hit me as I swimtorso, legs, ears maybe-but I am looking for debris

15. The body unperformed, unformed

16. Today, my son asks me his birth story and I think: I was happy to see you but missed keeping you close, but I say: you were easy and I felt nothing. We look outside while the leaves of star apples are buried by rain. I want to take him out, jump on puddles, but the potholes are deep, water's dirty. So we wait for the sun 


\section{PROVISIONARY OVERTURE}

Vat of water, holy and stagnant

She was divided between two cities

Head in the first, heart in the river

Didn't hear him running to the bathroom

They soon lay eggs

It was easy to say I fell asleep

Her father had to come in, identify without a face

Head too big on him, lost his balance

The certainty of the mole on her shoulder

There was no way he could breathe

One could get by with templates

The mosquitoes have copied themselves copiously

Stuck in one place, her head has not reached her father

reaching for the coin too

Listen, if you were a baby, you'd have kept

The decision to end was easy. The follow through harder

So familiar, he cried and kissed her shoulder

They are everywhere at once

Cannot move yet. He thinks he'll be taken back to the womb

Kritika Kultura 35 (2020): 291-295

(c) Ateneo de Manila University

<http://journals.ateneo.edu/ojs/kk/> 
The head is cleanly cut, as a jigsaw's

Shiny like a silvery minnow in this storybook

Spit and mucus on the mole

The female leaves her children, looking for new blood

thrashing in the water

In the province, she would have heard him

These are nice coincidences

I place his tiny head gently under, then allow him breath again

Slowly I let him go. He thrashes about

The head will be placed in an ice box for rush delivery

She worked as a maid. She had a good place

First meal over. Now is the hour of breeding

the bucket. Reached for it at the bottom

He was playing with the coin. Threw it into

I look at the showerhead as it looks at me. I push his head down to make it quick

Don't throw it away. It has been blessed

He is rubbing his palms together, and presses them on her arms

That the head might make a match

for her boy

She was playing cards, hoping to win rice

They find him by the soles of his feet

Kritika Kultura 35 (2020): 292-295

(C) Ateneo de Manila University

<http://journals.ateneo.edu/ojs/kk/> 
A ringing. I snatch my hand back, as if burnt by his skin

The female finds her match

He is red all over

White as they pull him out

Blue and gags violently

You understand this desire to float

It's time for the three o'clock prayer

Kritika Kultura 35 (2020): 293-295

(c) Ateneo de Manila University

<http://journals.ateneo.edu/ojs/kk/> 


\section{PRESERVING THE MEMORY OF GLACIERS}

First year fallen to first world framing a skip, a stone. Forearms straight up, forecast fold, axis of self filling with form. Round and round she goes, control. Head back thrown a spinning sky, positive emotion. Centuries accumulate. Recover words in the ablation. History in an ice tube. Not exactly pure, I am part debris.

Out of my blue, recall the head upside down, legs dangling on monkey bars. Endure long cracks on surface like blood vessels. Engage flow, movement under own weightyou cannot see it unless time lapses. Them kids are all cheering: "collapse, collapse!" Those wonderful sounds for destruction. Abrasion. Plucking. Patient zero learning to till the land.

Though I have no knowledge of it, projection tells me it will be like burning, only leisure the pace of torture. Temperature keeps drowning at bay, our relationship cyclical: support in difficulty, ogives. The cold maintains composure. Fissures and crevasse give it texture. You will break me but the fog makes it clearer. A teacher pebbles ice-encased and a fan. A poet octopus with three hearts. 
Such a dramatic name for when cells stop growing.

The lady's palms are wet, the extraction a sizeable proof of life, leaving you with some illusion of permanence. A blip giving birth most overdone. A pod of narwhals purring. An astronaut recapturing days in orbit. He protects the cracked glass around Earth, while melting from radiotherapy. Unlike us, the river of ice does not forget when fragile: the happy making what's painful more painful. A geologist tells me: "The fate of the drill hole depends on whether the ice is compressed or stretched," meaning it can become bigger that it disappears or become smaller that it disappears. I say, "What do I know, I'm from the tropics." But faith in what remains-moraines, U-shaped valleys, striations, and for now, paid tours that wait for calving, this trip only worth the price if there's breakage to watch, shouts of praise as it materializes, millennia in seconds broken by clapping. A theory for happiness our language co-terminus I'm afraid that's a big wave 